\title{
Bacterial Communities in Marine Aerosols Revealed by 454 Pyrosequencing of the 16S rRNA Gene*
}

\author{
XIAOMIN XIA \\ Division of Environmental Science, Hong Kong University of Science and Technology, Clear Water Bay, Kowloon, \\ Hong Kong SAR, China \\ JiANJUN WANG, JiABIN Ji, JiEXIA ZHANG, AND LiQI CHEN \\ Key Laboratory of Global Change and Marine-Atmospheric Chemistry, Third Institute of Oceanography, State Oceanic \\ Administration, Xiamen, Fujian, China \\ RUI ZHANG \\ State Key Laboratory of Marine Environmental Science, Institute of Marine Microbes and Ecospheres, Xiamen University, \\ Xiamen, Fujian, China
}

(Manuscript received 31 December 2014, in final form 27 April 2015)

\begin{abstract}
Although bacteria are an important biological component of aerosol particles, studies of bacterial communities in remote marine aerosol are largely lacking. In this study, aerosol samples were collected over the western Pacific Ocean, the northern Pacific Ocean, the Arctic Ocean, and the Norwegian Sea during the Fifth Chinese National Arctic Research Expedition (CHINARE 5). The diversity and structure of aerosol bacterial communities, based on 454 pyrosequencing, were explored in these samples. The bacterial community in the aerosols collected over the Pacific Ocean was more diverse than over the Norwegian Sea. Both temporal and spatial variations in aerosol bacterial communities were observed based on phylogenetic analysis. These results suggest that the source of air masses shape bacterial communities in aerosol particles over remote marine regions. Aerosols are clearly important for long-range transport of bacteria. Since potential human pathogens (e.g., Streptococcus sp.) were retrieved in this study, further investigation is needed to evaluate the potential for their long-distance migration via aerosol.
\end{abstract}

\section{Introduction}

Aerosol bacteria, an important component of aerosol particles, have been studied for decades (Williamson and Gotaas 1942; Burrows et al. 2009; Després et al. 2012). Indoor aerosol bacteria have attracted more attention than outdoor counterparts because of their closer links with human health (Kedjarune et al. 2000;

\footnotetext{
* Supplemental information related to this paper is available at the Journals Online website: http://dx.doi.org/10.1175/JAS-D-150008.s1.

Corresponding author address: Liqi Chen, Key Laboratory of Global Change and Marine-Atmospheric Chemistry, Rm. 501, Third Institute of Oceanography, State Oceanic Administration, Xiamen Daxue Road, Xiamen, Fujian 361005, China.

E-mail: chenliqi@tio.org.cn; ruizhang@xmu.edu.cn
}

Chang and Chou 2011; Hospodsky et al. 2012; Leung et al. 2014). However, in recent years, the importance of outdoor aerosol bacteria in ecosystems and their influence on human economies has been recognized. Outdoor aerosol bacteria also play a role as cloud condensation nuclei (Bauer et al. 2003; Sun and Ariya 2006; Morris et al. 2011). Both Maron et al. (2005) and Bowers et al. (2011) suggested that outdoor aerosol bacteria could be used as an indicator for source, level, and type of pollution. In addition, the dispersion of aerosol bacteria could be influencing global microbial biodiversity (Hervàs et al. 2009; Yukimura et al. 2009; Peter et al. 2014).

Marine aerosols have two main sources: one is marine particles, and the other is the crustal input from land carried by wind (Kellogg and Griffin 2006). Marine aerosols originate from the marine environment through "bubble bursting"; they may contain sea salt, 
TABLE 1. Sampling and pyrosequencing information for this study.

\begin{tabular}{llccccccc}
\hline \hline & \multicolumn{1}{c}{ Location } & $\begin{array}{c}\text { Sampling } \\
\text { time }\end{array}$ & $\begin{array}{c}\text { Average wind } \\
\text { speed }\left(\mathrm{m} \mathrm{s}^{-1}\right)\end{array}$ & $\begin{array}{c}\text { Raw } \\
\text { sequences }\end{array}$ & $\begin{array}{c}\text { High-quality } \\
\text { sequences }\end{array}$ & $\begin{array}{c}\text { OTU } \\
\text { No. }\end{array}$ & $\begin{array}{c}\text { Chao } \\
\text { Coverage }\end{array}$ & $\begin{array}{c}\text { Shannon } \\
\text { index }\end{array}$ \\
index
\end{tabular}

marine organic particles, marine microorganisms, and fragments of marine life (Blanchard 1983; Pósfai et al. 2003; Leck and Bigg 2008). Unlike terrestrial aerosols, which originate from soil and mainly contain Grampositive and spore-forming bacteria, such as Bacillus sp. (Griffin et al. 2003; Merrill et al. 2006), marine aerosols contain a high abundance of Gram-negative bacteria originating from seawater (Pósfai et al. 2003; Cho and Hwang 2011).

Although the abundance of bacteria in marine air is markedly lower than their abundance in continental air (Burrows et al. 2009), marine bacterial aerosol has global ecological significance. Marine aerosol plays a role as a vector in the long-distance dispersal of bacterial species, resulting in cosmopolitan distributions of some bacteria (Aller et al. 2005). The dispersal of some bacteria and viruses, which have similar genomic structure to human pathogens, could potentially threaten human health (Thompson et al. 2005). However, the study of marine aerosol bacteria, especially in remote marine areas, is hindered by their low abundance (Burrows et al. 2009) and inherent sampling difficulty. Thus, knowledge of bacterial community composition of marine aerosol is still very limited.

Traditional microbiological techniques based on isolation are widely applied to study aerosol bacterial communities (Kellogg and Griffin 2006). Since many of these bacteria, especially marine bacteria, are uncultivable, these techniques usually underestimate the diversity of the marine aerosol bacterial community. However, the recently developed culture-independent molecular techniques can portray a more exact picture of this bacterial community. To date, there has only been one study on remote marine aerosol bacterial community composition using molecular methods, carried out by Cho and Hwang (2011) in the East Sea (Korea). This study found that the abundance of marine aerosol bacteria ranged from 0.7 to $1.2 \times 10^{3}$ cells per cubic meter and was dominated by Gammaproteobacteria and Bacteroidetes. Cho and Hwang (2011) also suggested that many uncultured bacteria occur in marine aerosol, suggesting that the bacterial community in marine aerosol is complex and diverse.

The goal of this study was to document the composition of bacterial communities in aerosol samples collected over the Pacific Ocean, Norwegian Sea, and the Arctic Ocean during the Fifth Chinese National Arctic Research Expedition (CHINARE 5) cruise based on 454 pyrosequencing. To the best of our knowledge, this is the first study that applies highthroughput next-generation sequencing techniques to investigate marine aerosol bacterial community composition. Compared with clone library analysis, which is widely used in molecular ecology studies, pyrosequencing technology provides larger coverage and deeper sequencing depth, resulting in a better understanding of bacterial community composition (Sogin et al. 2006).

\section{Methods}

\section{a. Sample collection and backward trajectory analysis}

CHINARE 5 was carried out from July to September 2012. During the cruise, bulk aerosol samples were collected by a high-volume bulk sampler (Model M241; University of Miami, Florida), with a wind direction and speed controller, installed on the upper deck of the Research Vessel Xue Long. Samples were collected on a $20 \mathrm{~cm} \times 25 \mathrm{~cm}$ glass fiber filter $(1.0-\mu \mathrm{m}$ pore size; Pall Corporation, New York) for around 9-14 days, with a sampling flow rate of approximately $1 \mathrm{~m}^{3} \mathrm{~min}^{-1}$ (Table 1 ). The wind direction and speed controller was used during sampling to avoid contamination from the ship stack emission. In addition, a filter installed in a sampler with the pump turned off was collected as a blank control to evaluate potential contamination.

Four aerosol samples were collected over the western Pacific Ocean in July (WP-J) and September (WP-S), the northern Pacific Ocean in September (NP-S), and the Norwegian Sea in August (NS-A) (Fig. 1). These filters were frozen at $-80^{\circ} \mathrm{C}$ immediately after sampling.

The Hybrid Single-Particle Lagrangian Integrated Trajectory (HYSPLIT) transport and dispersion model from the NOAA Air Resources Laboratory (available online at http://www.arl.noaa.gov/ready/hysplit4.html) (Draxler and Rolph 2003) was applied to calculate airmass backward trajectories (BTs) for the samples. For each sample, 5-day backward trajectories were traced from the start to end points of the sampling interval, with 


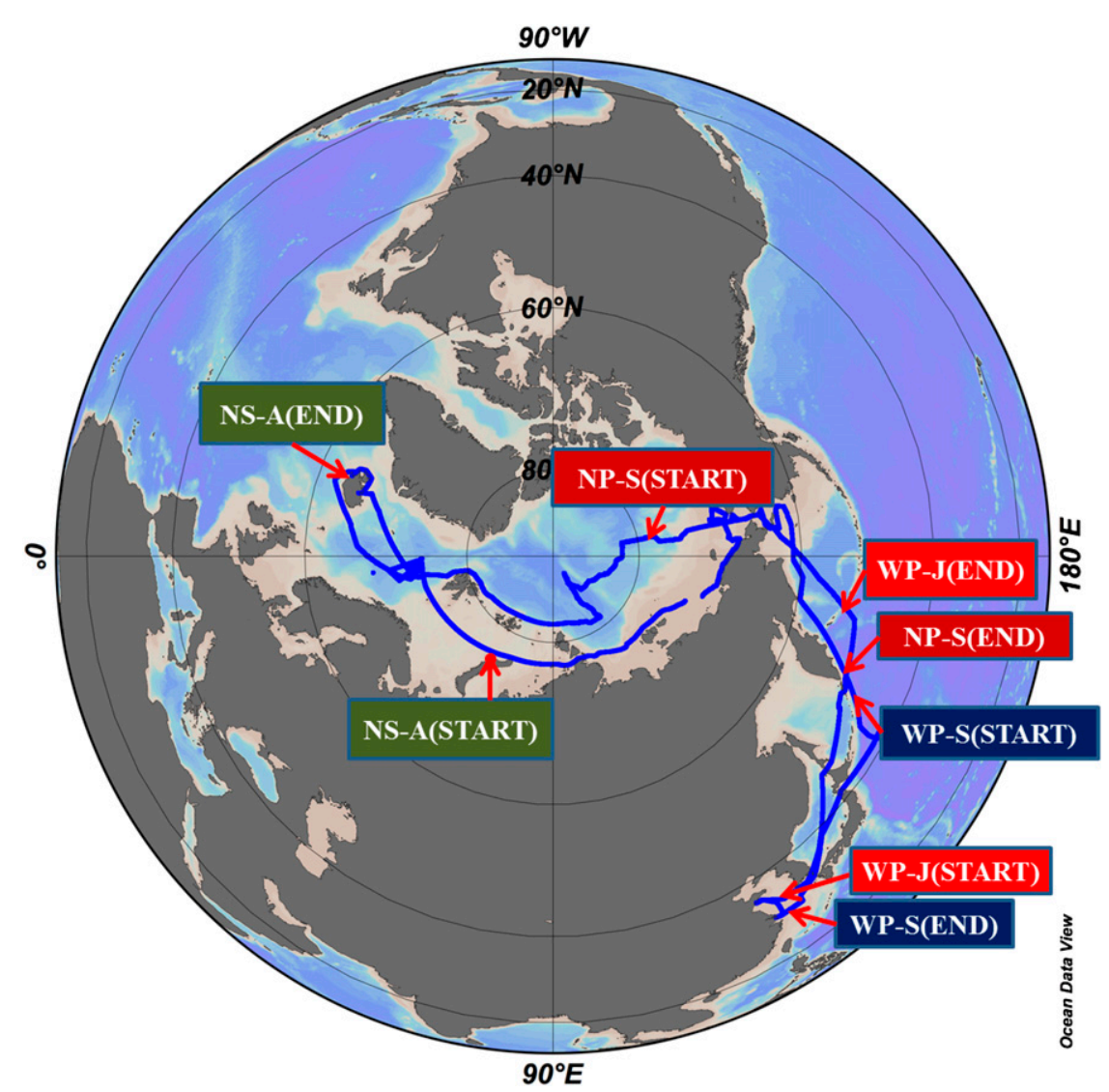

FIG. 1. Trace of the CHINARE 5 cruise and the locations of the aerosol samples for bacterial diversity analysis.

12-h steps, at various heights $(0,100$, and $500 \mathrm{~m})$ above sea level.

\section{b. DNA extraction}

Bacterial deoxyribonucleic acid (DNA) was extracted from aerosol samples and blank controls using a modified enzyme/phenol-chloroform protocol (Tsai and Olson 1991). A $30 \mathrm{~mm} \times 30 \mathrm{~mm}$ piece of membrane sample was cut into small pieces and put into a $15-\mathrm{mL}$ tube with $4 \mathrm{~mL}$ of solution I buffer [Tris- $\mathrm{HCl} 25 \mathrm{mM}$, ethylenediaminetetraacetic acid (EDTA) $10 \mathrm{mM}$, and sucrose $50 \mathrm{mM} ; \mathrm{pH}$ 8.0]. Before adding phenolchloroform, the following steps were applied. First, the sample was mixed well by vertex and sonicated for $2 \mathrm{~min}$. Next, $40 \mu \mathrm{L}$ of $40 \mathrm{mg} \mathrm{mL}^{-1}$ lysozyme was added and incubated at $37^{\circ} \mathrm{C}$ for $2 \mathrm{~h}$; then $400 \mu \mathrm{L}$ of $10 \%$ sodium dodecyl sulfate (SDS) and $40 \mu \mathrm{L}$ of $20 \mathrm{mg} \mathrm{mL}^{-1}$ proteinase $\mathrm{K}$ were added, and this was incubated at $55^{\circ} \mathrm{C}$ for $2 \mathrm{~h}$. Finally, the tube was centrifuged at $1700 \mathrm{~g}$ for $10 \mathrm{~min}$, and the supernatant was transferred into new $1.5-\mathrm{mL}$ tubes and added to $5 \mathrm{M} \mathrm{NaCl}(225 \mu \mathrm{L} \mathrm{NaCl}$ per 4-mL sample). After phenol-chloroform extraction,
DNA was purified using PureLink Genomic DNA kits and eluted in a $30-\mu \mathrm{L}$ elution buffer (Thermo Fisher Scientific, California).

\section{c. PCR and sequencing}

The bacterial 16S ribosomal ribonucleic acid (rRNA) gene was amplified using universal 16S rRNA gene primers (27F and 1492R) (Ludwig and Schleifer 1994) and barcoded primers (341F and 806R) (Yu et al. 2005). The first round of polymerase chain reaction (PCR) used the primers $27 \mathrm{~F}$ and $1492 \mathrm{R}$, and its products were used as templates for the second round of PCR, using barcoded primers $341 \mathrm{~F}$ and $806 \mathrm{R}$. The $25-\mu \mathrm{L}$ PCR reaction mixture contained a final concentration of $0.5 \mathrm{mM} \mathrm{MgCl} 2$, $0.5 \mu \mathrm{M}$ of each primer, $0.8 \mathrm{mM}$ of each deoxynucleotide (dNTP), 1.0 unit of hot start polymerase (Thermo Fisher Scientific) and $1 \mu \mathrm{L}$ temperate DNA. The PCR cycles started with a 5 -min initial denaturation at $95^{\circ} \mathrm{C}$, followed by 30 cycles at $95^{\circ} \mathrm{C}$ for $30 \mathrm{~s}, 55^{\circ} \mathrm{C}$ for $30 \mathrm{~s}$, and $72^{\circ} \mathrm{C}$ for $60 \mathrm{~s}$. A final extension of $72^{\circ} \mathrm{C}$ for $5 \mathrm{~min}$ was included before holding at $4^{\circ} \mathrm{C}$. All the reactions were done in triplicate. PCR products were gel purified using a 
QIAquick gel purification kit (Qiagen, Germany) as described by the manufacturer. The amplicons were then mixed in equal amounts and sequenced using a GS FLX pyrosequencing system (Roche, 454 Life Sciences, Connecticut). No $16 \mathrm{~S}$ ribosomal RNA (rRNA) gene was amplified from the blank control filters, indicating bacteria contamination in the filters over the sampling period was too low to influence our results.

\section{d. Phylogenetic and statistical analysis}

Analysis of 16S rRNA sequences was conducted using the microbial ecology community software program mothur (available online at http://www.mothur.org/ wiki/Download_mothur; Schloss et al. 2009). The reads were processed by removing tags and primers. Only reads with an average quality score above 20 and read lengths between 300 and $500 \mathrm{nt}$ were accepted. The sequence denoise was carried out using the command shhh.seqs. Sequences that did not align in the same region as most other sequences were screened and removed. Chimeras were analyzed using the mothur software package with the command chimera.uchime (Schloss et al. 2011). The operational taxonomic units (OTUs) containing only one sequence were also discarded. Sample coverage, abundance-base coverage estimator (ACE) richness estimators, and the Shannon diversity index were calculated at $97 \%$ similarity. Sequences were classified using the greengenes database (http://greengenes.lbl.gov/ cgi-bin/nph-index.cgi) (DeSantis et al. 2006). An unweighted pair group method with arithmetic mean (UPGMA) analysis was applied to compare the bacterial community compositions in the aerosol samples using Primer 5 (Primer-E, Ltd., United Kingdom; available online at http://www.primer-e.com).

From each sample, 20000 sequences were randomly extracted and classified. Each classification result was summarized and used to generate a Venn diagram using R. A neighbor-joining phylogenetic tree of 16S rRNA genes was constructed in Molecular Evolutionary Genetics Analysis software, version 4 (MEGA 4; Tamura et al. 2007), using representative sequences at a 0.03 genetic distance. Nearest relatives were retrieved from the National Center for Biotechnology Information (NCBI) database (Sayers et al. 2011). A heat map showing the relative abundance of each OTU was generated in the Interactive Tree of Life (iTOL; Letunic and Bork 2007).

\section{Results}

\section{a. Backward trajectory analysis}

Analysis of airmass backward trajectories shows all samples were collected from mixed continental and oceanic air masses (Fig. 2 and supplemental material Fig. S1). The continental air masses collected by NP-S and WP-S were mainly from northern China, while those collected by WP-J were mainly from eastern China (Fig. 2). Marine air masses collected by WP-J and WP-S mainly originated from the Bering Sea and the central Pacific Ocean, respectively (Figs. 2a,d). The air masses for NS-A were from the Arctic Ocean, the Norwegian Sea, and Greenland (Fig. 2b).

\section{b. Pyrosequencing analysis}

We obtained 165813 raw 16S rRNA gene sequences from four samples. After removing the noise, poorquality reads, and chimera sequences, 143982 highquality sequences remained for further analysis. All raw sequences obtained from this study have been deposited in the NCBI Sequence Read Archive (SRA) under accession numbers SRR1735298-SRR1735301. At 97\% similarity, Good's coverage estimates of all samples were higher than 0.99 (Table 1), which indicates the sequencing effort covered the major extent of the taxonomic diversity. Rarefaction curves for all samples reached saturation (Fig. 3a), indicating the sequencing capacity covered most of the taxonomic units. At $3 \%$ phylogenetic distance, after removing rare OTUs that contained only a single sequence, 601 OTUs remained. Numbers of OTUs in samples collected from the Pacific Ocean were higher than from the Norwegian Sea. In the Pacific Ocean, more OTUs occurred in September than in July (Table 1).

\section{c. Diversity of aerosol bacteria communities}

Bacterial community diversity was estimated using the Shannon and ACE indices. The Shannon diversity index of the four aerosol bacterial communities ranged from 1.50 to 2.41. NS-A had the lowest bacterial species richness and diversity, while the highest community diversity was detected in NP-S (Table 1). In aerosols over the western Pacific Ocean, bacterial species richness was higher in September than in July. Based on the mothur thetayc calculator, NP-S and WP-S had the highest similarity (54.4\%) (Fig. 3b). Distances between NP-S and other samples were larger than $99.9 \%$, which indicates that the bacterial community composition of NP-S was markedly different from the other aerosol samples.

\section{d. Bacterial community composition in aerosol samples}

Both Gram-negative and Gram-positive bacteria were detected in all aerosol samples. The percentage of Gram-positive bacteria was higher than that of Gramnegative bacteria in the samples collected over the $\mathrm{Pa}$ cific Ocean, while the opposite pattern was observed in the sample collected from the Norwegian Sea. In the 

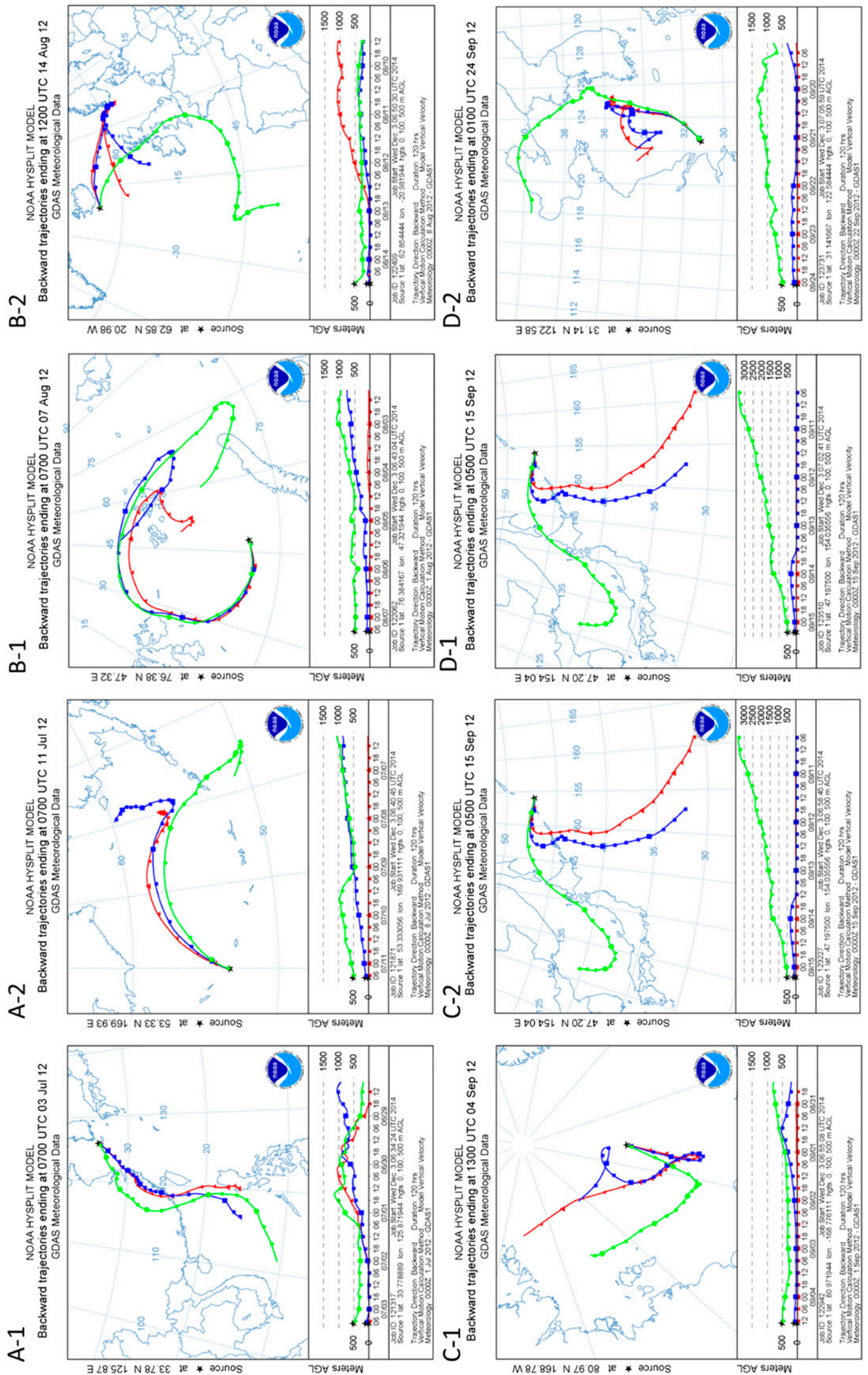

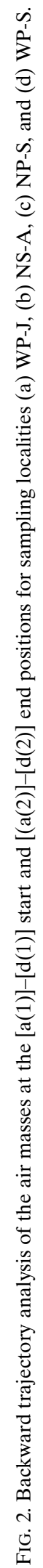




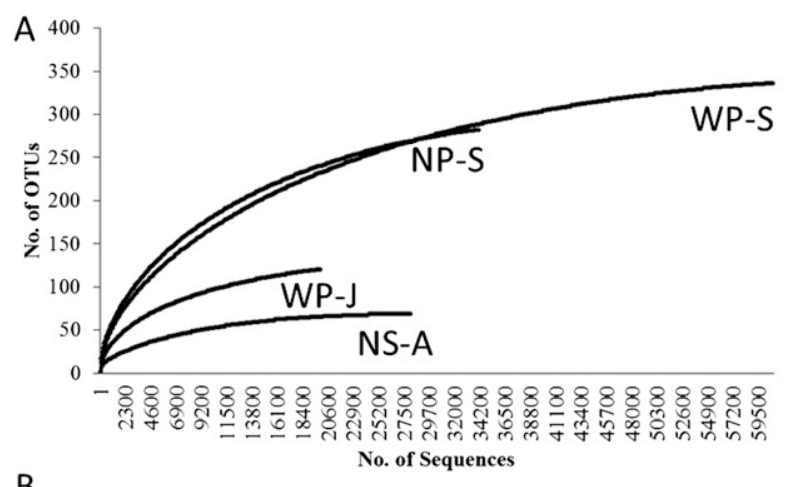

B
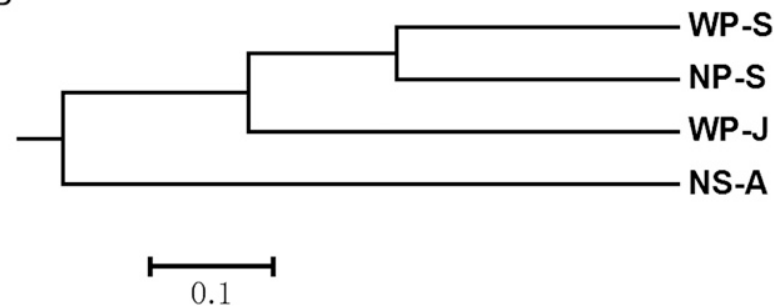

FIG. 3. (a) Rarefaction curves and (b) UPGMA plotting of aerosol bacterial communities at the $97 \%$ sequence similarity cutoff value.

aerosol particles over the Pacific Ocean, the percentage of Gram-negative bacteria was lowest in July (Fig. 4a).

Based on the greengenes database, all 16S rRNA gene sequences were affiliated with five known bacterial phyla, with confidence score thresholds of $60 \%$. As a whole, the most abundant bacterial phylum/subphylum found in aerosol samples was Firmicutes $(49.66 \%$ of total sequences), followed by Proteobacteria (48.17\%). In the phylum Proteobacteria, Alphaproteobacteria (10.72\%), Betaproteobacteria (2.23\%), and Gammaproteobacteria $(35.21 \%)$ were detected. Cyanobacteria were only detected in the aerosol over the northern Pacific Ocean (Fig. 4b). At the phylum/subphylum level, Firmicutes, Gammaproteobacteria and Alphaproteobacteria were detected in all aerosol samples. In comparison, the relative abundance of Firmicutes was higher in the samples collected over the western Pacific aerosol than in other samples, although this phylum was represented by different bacterial genera in the four aerosol samples (Fig. 4c). Alphaproteobacteria mainly occurred in the Norwegian Sea aerosol in April, while Gammaproteobacteria dominated the Pacific aerosol in September (Fig. 4b).

In aerosol samples, 19 bacterial orders were present (Fig. 5), although no bacterial order was shared by all four aerosol bacterial communities. Bacillales was the most common bacterial order in the Pacific Ocean aerosol, while Sphingomonadales, Vibrionales, and Lactobacteriales, which were rarely found in other samples, were the dominant bacterial orders in aerosol particles over the Norwegian Sea. In aerosol over the

\section{A}
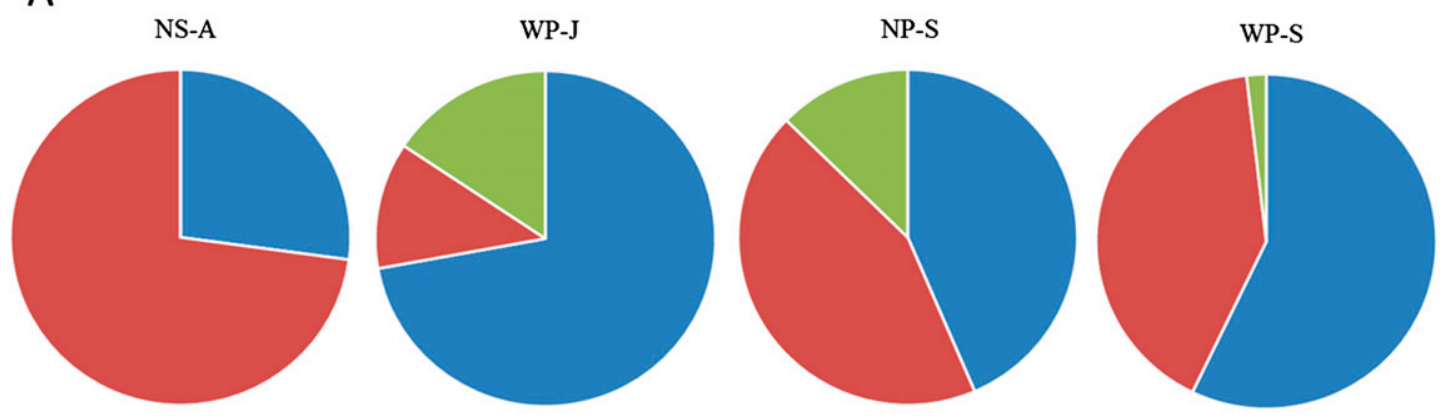

- positive

- negative

" unknown

B

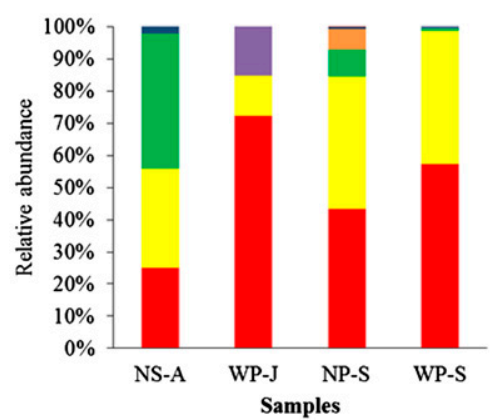

C

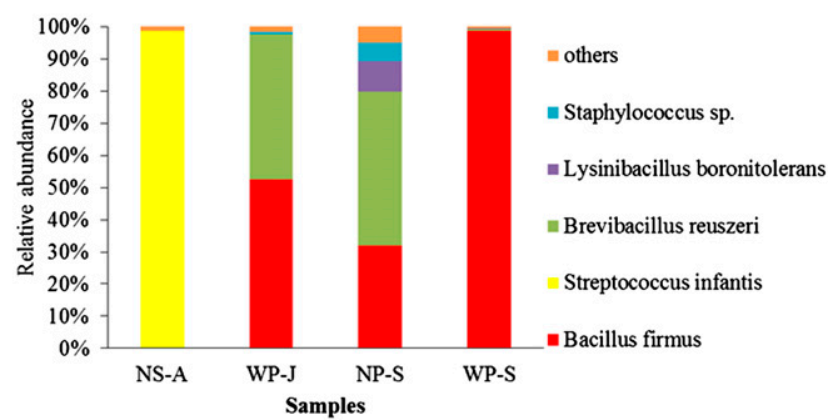

FIG. 4. (a) Percentage of Gram-positive and Gram-negative bacteria in the four aerosol samples, (b) relative abundance of bacterial phyla in these four aerosol samples, and (c) the genus-level composition of bacteria from the phylum Firmicutes. 

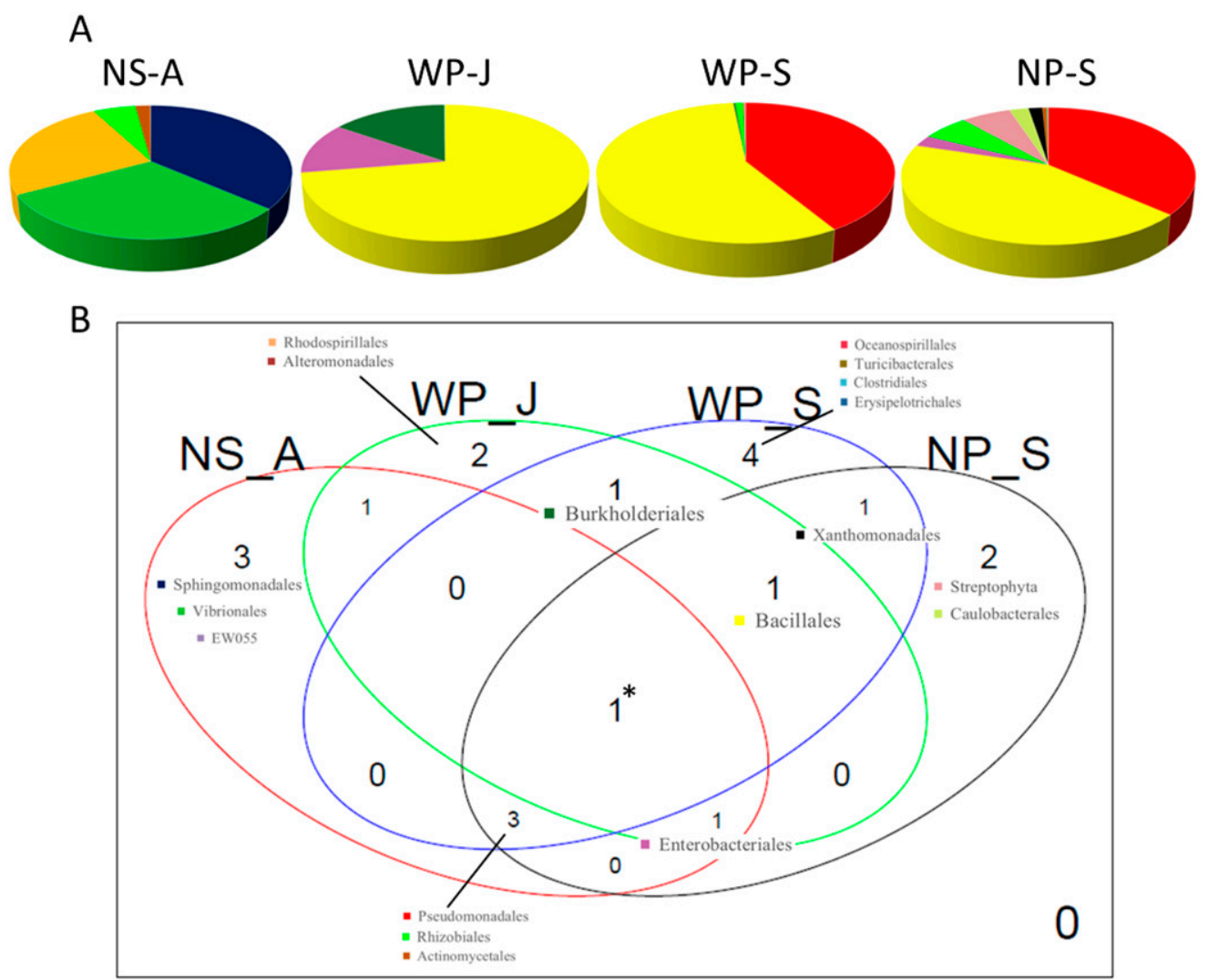

- Pseudomonadales Bacillales

- Sphingomonadales

- Vibrionales

- Lactobacillales

- Enterobacteriales

- Burkholderiales

- Rhizobiales

- Streptophyta

1 Caulobacterales

- Xanthomonadales

- Actinomycetales

- Oceanospirillales

- unclassified

- Turicibacterales

- EW055

- Clostridiales

- Rhodospirillales

- Erysipelotrichales

- Alteromonadales

FIG. 5. (a) Relative abundance of different bacteria orders in the four aerosol samples and (b) the relationship between aerosol bacterial communities at order level. An asterisk indicates an unclassified bacterial order.

western Pacific Ocean, in addition to Bacillales, Burkholderiales was detected; this bacterial order had higher relative abundance in July than in September. In September, Xanthomonadales, Bacillales, Pseudomonadales, Rhizobiales, and Actinomycetales could be detected in aerosols over both the western and northern Pacific Ocean. In these two aerosol samples, Pseudomonadales was the second most abundant bacterial order. Enterobacteriales, which mainly dominated the western Pacific aerosol in July, was also detected in the air over the Norwegian Sea and the northern Pacific, but with lower abundance.

At the genus level, $87.41 \%$ of total sequences were assigned to 35 bacterial genera, of which Bacillus, Pseudomonas, and Brevibacillus were the most abundant. Marine Pseudoalteromonas also was detected in high abundance. Several genera were potential human pathogens, such as Streptococcus infantis, Staphylococcus sp., and Propionibacteriom acnes (Fig. 6). Bacillus firmus was the dominant bacteria in the Pacific aerosol, especially in the aerosol over the western Pacific Ocean. In the western Pacific aerosol, Brevibacillus sp. was the second predominant bacteria in July, while its abundance decreased and was replaced by Pseudomonas sp. in September. In contrast to the bacterial community in the Pacific aerosol, the most abundant bacterial genera in the Norwegian Sea aerosol were unclassified Sphingomonadaceae (marine origin), Pseudoaltermonas sp. (marine origin), and Streptococcus sp. (human pathogen). Such bacteria were rare in the Pacific Ocean aerosol (Figs. 6 and 7).

Figure 7 shows that in the top 100 abundant OTUs, two bacillus species, B. firmus and B. flexus, were documented: 14 OTUs were affiliated with $B$. firmus, and 3 OTUs were affiliated with Bacillus flexus. OTU00001 was the most abundant OTU detected in WP-J, NP-S, and WP-S. Some OTUs affiliated with B. firmus, such as OTU00016, OTU00017, and OTU00024, could only be detected in WP-J and WP-S. Chloroplast could only be detected in NP-S and consisted of five OTUs.

\section{Discussion}

Aerosol plays a vital role in the interaction between terrestrial and marine ecosystems. Crustal materials originating from land in aerosol form invade the marine 


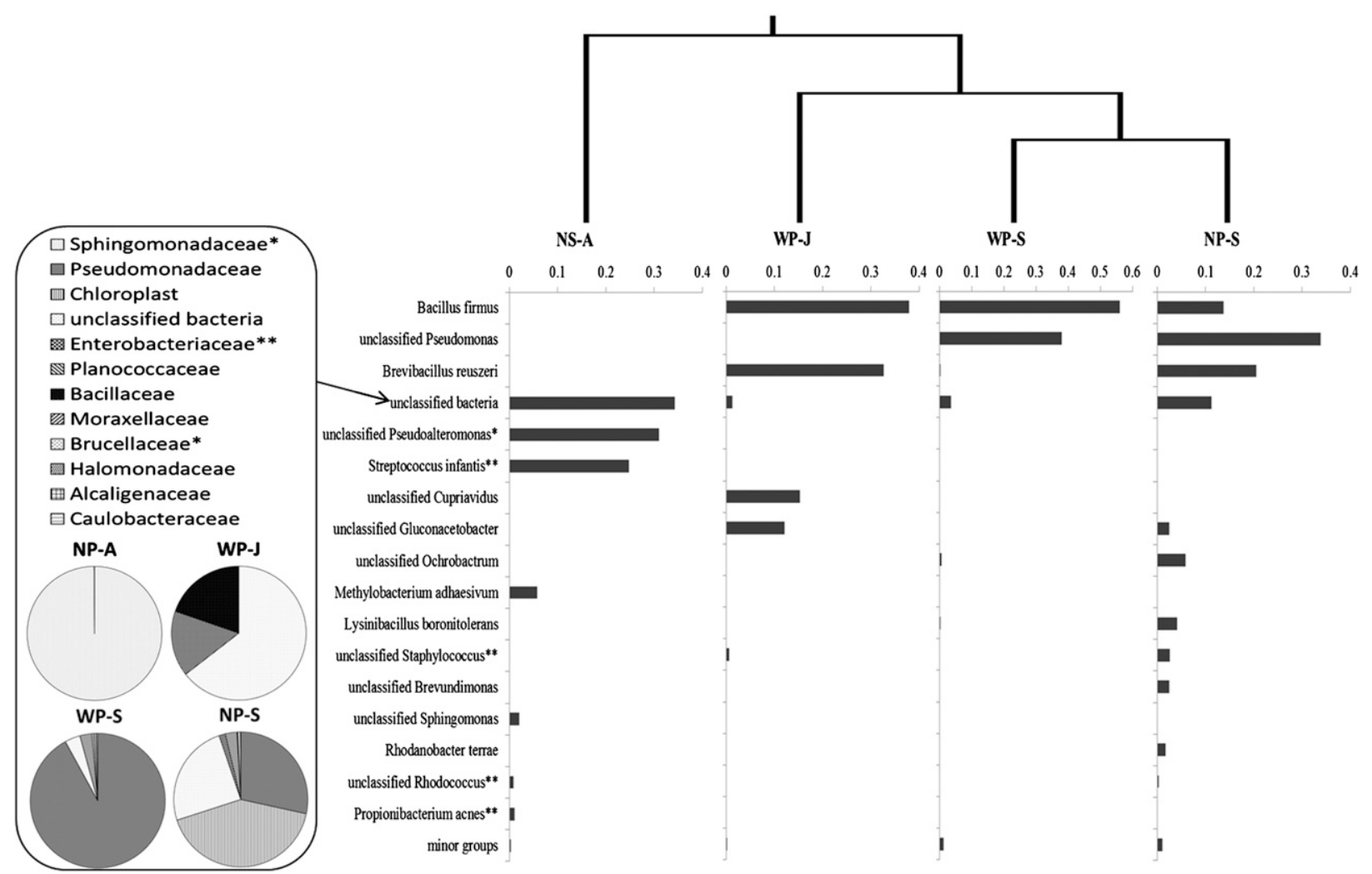

FIG. 6. Relative abundance of bacterial genera (based on classification of top 100 most abundant OTUs). One asterisk indicates bacteria originating from marine water and two asterisks indicate a human pathogen.

environment and influence its ecosystem (Iwamoto et al. 2011; Tan et al. 2013). Marine materials (including organic and inorganic particles and microorganisms), on the other hand, are released directly into the air (Gershey 1983; O’Dowd et al. 2004) and transported into the terrestrial ecosystem by wind. Bacteria are the most abundant and diverse organisms on Earth; they are widely distributed in aerosol. However, based on traditional incubation methods and microscopy analysis, both the diversity and abundance of marine aerosol bacteria were thought to be relatively low (Pósfai et al. 2003; Hultin et al. 2011). However, our study using a high-throughput next-generation sequencing technique detected more than 600 OTUs and 40 genera of bacteria in only four aerosol samples. This indicates that the bacterial community in marine aerosols is more diverse than previously thought.

If the outdoor aerosol bacterial community is affected by the source and transport pathways of air masses, then bacteria can be indicators for aerosol source (Jeon et al. 2011). In this study, we found the source of air masses played an important role in shaping marine aerosol bacterial community compositions (Figs. 3b, 6, 7). For example, the general bacterial community in the aerosol over the Pacific Ocean and the Norwegian Sea were markedly different. This is consistent with our analysis of airmass backward trajectories that showed aerosol over the Pacific Ocean was mainly from air masses from the adjacent continent, while aerosol over the Norwegian Sea was mainly from air masses over marine environments. Crustal materials originating from northern Asia were reported to be influencing the eastern coast of China (Li et al. 2011), Korea (Ma et al. 2004), Japan (Hua et al. 2007), the western Pacific Ocean (Bishop et al. 2002; Uno et al. 2009), and North America (Smith et al. 2013). Bacillus sp., which are typical soil bacteria, were reported to be the major aerosol bacteria in marine aerosol over Asia and could easily be transported to Korea, Japan, and even farther to North America (Hua et al. 2007; Maki et al. 2010; Smith et al. 2013; An et al. 2014). In this study, we also note that Bacillus sp. was a core species in the aerosol bacterial community over the Pacific Ocean (Figs. 6, 7), suggesting that bacteria from the continent (Fig. 2) can reach the northern Pacific Ocean, forming a major component of the Pacific aerosol bacteria. In comparison with the abundance of bacteria from crustal sources, bacteria from marine sources were less abundant. Furthermore, soil bacteria 


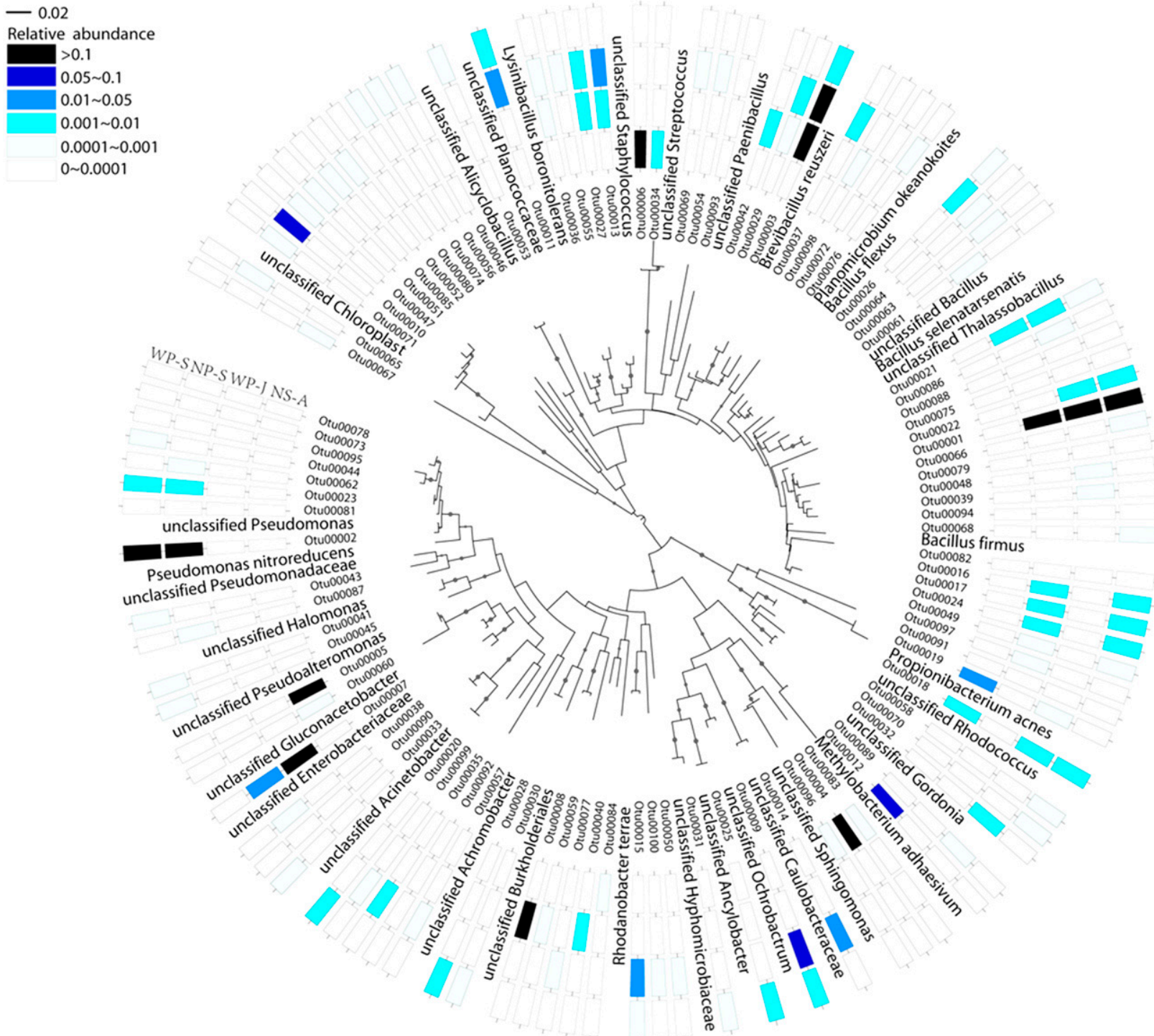

FIG. 7. Neighbor-joining phylogenetic tree for the top 100 OTUs at the $97 \%$ similarity level. Bootstrap values (1000 replicates) greater than $50 \%$ are indicated with size-proportioned black circles. The relative abundance of each OTU is indicated by the color bar.

dominated samples collected over the Pacific Ocean at different times, indicating crustal materials from Asia continuously influence the ecosystem of the northern Pacific Ocean. Therefore, as a vector for long-range dispersion of microorganisms, aerosols may influence local bacterial community composition.

In addition, airmass backward trajectory analysis showed that air masses collected over the Pacific Ocean in July and September mainly came from eastern and northern China, respectively. The difference in aerosol source may explain the temporal variation in aerosol bacteria over the western Pacific Ocean observed in our study. For example, Bacillus sp., Cupriavidus sp., and Gluconacetobater sp. were common in July, while
Pseudomonas sp. was dominant in September. We propose that these bacteria species could be indicators for variation in aerosol sources over the western Pacific Ocean.

In contrast, the aerosols over the Norwegian Sea contain a high abundance of microbial particle from marine environments. Microbial aerosols from marine environment are dominated by Gram-negative bacteria (Pósfai et al. 2003; Cho and Hwang 2011). Studies using molecular methods revealed that Sphingomonas sp. and Pseudoalteromonas sp. are the main bacteria species in air masses collected over marine environments (Fahlgren et al. 2010; Cho and Hwang 2011). This study showed that the Gram-negative bacteria occurring in aerosol over the Norwegian Sea also were Sphingomonadaceae 
and Pseudoaltermonas sp. Our results suggest there is a stronger marine influence on aerosol over the Norwegian Sea than over the Pacific Ocean. This was supported by the relatively higher wind speed documented during aerosol sampling over the Norwegian Sea (Table 1). Please note that analyses of chemical compositions of aerosol samples are needed to support this hypothesis. Interestingly, our study showed that dominant marine bacterial lineages, such as SAR11, Rhodobacteria, and picophytoplankton, were absent in aerosol samples, even though we used high-throughput deep sequencing. Possibly, these species cannot tolerate the harsh environment of aerosols over the ocean, such as exposure to high doses of UV light (Aller et al. 2005); most marine bacteria could not survive and grow as aerosols (Fahlgren et al. 2010).

Pathogens can be transported long distances as aerosol (Polymenakou et al. 2008). For example, pathogens originating from Asia were detected in air samples collected in North America (Smith et al. 2012); pathogens may also be transported from Africa to Europe by African dust storms (Polymenakou et al. 2008). In this study, several potential human pathogens were detected in marine aerosol samples, such as $S$. infantis, $P$. acnes, and Staphylococcus sp. The former two pathogens occurred in air over the Norwegian Sea. Using backward trajectory analysis, these pathogens appear to originate from Greenland. Streptococcus sp. was only detected in April, when air masses were from the Baltic Sea and Russia (Fahlgren et al. 2010). The presence of potential human pathogens in remote marine areas indicates that aerosol transport is a vector for the spread of human diseases. Further studies of marine aerosol bacteria in different marine areas may show that long-distance migration of human pathogens occurs as aerosols.

\section{Conclusions}

The development of new molecular technology in recent years allows us to study bacterial diversity and community composition in marine aerosols. This study suggests that the marine aerosol bacterial community is more diverse than previously thought. Its composition is clearly shaped by the sources of its air mass. Our results also suggest that aerosol bacteria could be indicators for marine aerosols. Moreover, even in remote marine air far from human activities, human pathogens were still detected. Further research on the activity of marine aerosol bacteria may help us understand global dispersion of bacteria through aerosol transport.

Acknowledgments. Xiaomin Xia and Jianjun Wang contributed equally to this work. This work was funded by the NSFC (41230529, 41476172), Chinese Projects for Investigations and Assessments of the Arctic and Antarctic (CHINARE2012-15 for 01-04-02, 02-01, and 03-04-02), Chinese International Cooperation Projects (2015DFG22010, IC201201, IC201308, IC201504, and IC201513), and the Scientific Research Foundation of the Third Institute of Oceanography (2014031). R. Zhang was partially supported by Grant GCMAC1201.

\section{REFERENCES}

Aller, J. Y., M. R. Kuznetsova, C. J. Jahns, and P. F. Kemp, 2005: The sea surface microlayer as a source of viral and bacterial enrichment in marine aerosols. J. Aerosol Sci., 36, 801-812, doi:10.1016/j.jaerosci.2004.10.012.

An, S., H. Sin, and M. DuBow, 2014: Modification of atmospheric sand-associated bacterial communities during Asian sandstorms in China and South Korea. Heredity, 114, 460-467, doi:10.1038/hdy.2014.102.

Bauer, H., H. Giebl, R. Hitzenberger, A. Kasper-Giebl, G. Reischl, F. Zibuschka, and H. Puxbaum, 2003: Airborne bacteria as cloud condensation nuclei. J. Geophys. Res., 108, 4658, doi:10.1029/2003JD003545.

Bishop, J. K., R. E. Davis, and J. T. Sherman, 2002: Robotic observations of dust storm enhancement of carbon biomass in the North Pacific. Science, 298, 817-821, doi:10.1126/ science.1074961.

Blanchard, D. C., 1983: The production, distribution, and bacterial enrichment of the sea-salt aerosol. Air-Sea Exchange of Gases and Particles, P. S. Liss and W. G. N. Slinn, Eds., NATO ASI Series C: Mathematical and Physical Sciences, Vol. 108, Springer Netherlands, 407-454.

Bowers, R. M., S. McLetchie, R. Knight, and N. Fierer, 2011: Spatial variability in airborne bacterial communities across land-use types and their relationship to the bacterial communities of potential source environments. ISME J., 5, 601612, doi:10.1038/ismej.2010.167.

Burrows, S., W. Elbert, M. Lawrence, and U. Pöschl, 2009: Bacteria in the global atmosphere-Part 1: Review and synthesis of literature data for different ecosystems. Atmos. Chem. Phys., 9, 9263-9280, doi:10.5194/acp-9-9263-2009.

Chang, C. W., and F. C. Chou, 2011: Methodologies for quantifying culturable, viable, and total Legionella pneumophila in indoor air. Indoor Air, 21, 291-299, doi:10.1111/ j.1600-0668.2010.00701.x.

Cho, B. C., and C. Y. Hwang, 2011: Prokaryotic abundance and 16S rRNA gene sequences detected in marine aerosols on the East Sea (Korea). FEMS Microbiol. Ecol., 76, 327-341, doi:10.1111/ j.1574-6941.2011.01053.x.

DeSantis, T. Z., and Coauthors, 2006: Greengenes, the 16S rRNA gene database and tools. The Greengenes Database Consortium, accessed 1 June 2013. [Available online at http://greengenes.lbl.gov/ cgi-bin/nph-index.cgi.]

Després, V. R., and Coauthors, 2012: Primary biological aerosol particles in the atmosphere: A review. Tellus, 64B, 15598 , doi:10.3402/tellusb.v64i0.15598.

Draxler, R. R., and G. Rolph, 2003: HYSPLIT (HYbrid SingleParticle Lagrangian Integrated Trajectory) Model. NOAA Air Resources Laboratory, Silver Springs, MD, accessed 3 December 2014. [Available online at http://www.arl.noaa.gov/ ready/hysplit4.html.] 
Fahlgren, C., Å. Hagström, D. Nilsson, and U. L. Zweifel, 2010: Annual variations in the diversity, viability, and origin of airborne bacteria. Appl. Environ. Microbiol., 76, 3015-3025, doi:10.1128/AEM.02092-09.

Gershey, R. M., 1983: Characterization of seawater organic matter carried by bubble-generated aerosols. Limnol. Oceanogr., 28, 309-319, doi:10.4319/1o.1983.28.2.0309.

Griffin, D. W., C. A. Kellogg, V. H. Garrison, J. T. Lisle, T. C. Borden, and E. A. Shinn, 2003: Atmospheric microbiology in the northern Caribbean during African dust events. Aerobiologia, 19, 143-157, doi:10.1023/B:AERO.0000006530.32845.8d.

Hervàs, A., L. Camarero, I. Reche, and E. O. Casamayor, 2009: Viability and potential for immigration of airborne bacteria from Africa that reach high mountain lakes in Europe. Environ. Microbiol., 11, 1612-1623, doi:10.1111/j.1462-2920.2009.01926.x.

Hospodsky, D., J. Qian, W. W. Nazaroff, N. Yamamoto, K. Bibby, H. Rismani-Yazdi, and J. Peccia, 2012: Human occupancy as a source of indoor airborne bacteria. PLoS One, 7, e34867, doi:10.1371/journal.pone.0034867.

Hua, N.-P., F. Kobayashi, Y. Iwasaka, G.-Y. Shi, and T. Naganuma, 2007: Detailed identification of desert-originated bacteria carried by Asian dust storms to Japan. Aerobiologia, 23, 291298, doi:10.1007/s10453-007-9076-9.

Hultin, K. A., R. Krejci, J. Pinhassi, L. Gomez-Consarnau, E. M. Mårtensson, Å. Hagström, and E. D. Nilsson, 2011: Aerosol and bacterial emissions from Baltic Seawater. Atmos. Res., 99, 1-14, doi:10.1016/j.atmosres.2010.08.018.

Iwamoto, Y., K. Yumimoto, M. Toratani, A. Tsuda, K. Miura, I. Uno, and M. Uematsu, 2011: Biogeochemical implications of increased mineral particle concentrations in surface waters of the northwestern North Pacific during an Asian dust event. Geophys. Res. Lett., 38, L01604, doi:10.1029/ 2010GL045906.

Jeon, E. M., H. J. Kim, K. Jung, J. H. Kim, M. Y. Kim, Y. P. Kim, and J.-O. Ka, 2011: Impact of Asian dust events on airborne bacterial community assessed by molecular analyses. Atmos. Environ., 45, 4313-4321, doi:10.1016/ j.atmosenv.2010.11.054.

Kedjarune, U., B. Kukiattrakoon, B. Yapong, S. Chowanadisai, and P. Leggat, 2000: Bacterial aerosols in the dental clinic: Effect of time, position and type of treatment. Int. Dent. J., 50, 103-107, doi:10.1002/j.1875-595X.2000.tb00807.x.

Kellogg, C. A., and D. W. Griffin, 2006: Aerobiology and the global transport of desert dust. Trends Ecol. Evol., 21, 638-644, doi:10.1016/j.tree.2006.07.004.

Leck, C., and E. K. Bigg, 2008: Comparison of sources and nature of the tropical aerosol with the summer high Arctic aerosol. Tellus, 60B, 118-126, doi:10.3402/tellusb.v60i1.16906.

Letunic, I., and P. Bork, 2007: Interactive Tree Of Life (iTOL): An online tool for phylogenetic tree display and annotation. Bioinformatics, 23, 127-128, doi:10.1093/bioinformatics/ bt1529.

Leung, M. H., D. Wilkins, E. K. Li, F. K. Kong, and P. K. Lee, 2014: Indoor-air microbiome in an urban subway network: Diversity and dynamics. Appl. Environ. Microbiol., 80, 6760-6770, doi:10.1128/AEM.02244-14.

Li, M., J. Qi, H. Zhang, S. Huang, L. Li, and D. Gao, 2011: Concentration and size distribution of bioaerosols in an outdoor environment in the Qingdao coastal region. Sci. Total Environ., 409, 3812-3819, doi:10.1016/j.scitotenv.2011.06.001.

Ludwig, W., and K. Schleifer, 1994: Bacterial phylogeny based on 16S and 23S rRNA sequence analysis. FEMS Microbiol. Rev., 15, 155-173, doi:10.1111/j.1574-6976.1994.tb00132.x.
Ma, C.-J., S. Tohno, M. Kasahara, and S. Hayakawa, 2004: Properties of individual Asian dust storm particles collected at Kosan, Korea during ACE-Asia. Atmos. Environ., 38, 11331143, doi:10.1016/j.atmosenv.2003.11.020.

Maki, T., and Coauthors, 2010: Phylogenetic analysis of atmospheric halotolerant bacterial communities at high altitude in an Asian dust (KOSA) arrival region, Suzu City. Sci. Total Environ., 408, 4556-4562, doi:10.1016/j.scitotenv.2010.04.002.

Maron, P.-A., D. P. Lejon, E. Carvalho, K. Bizet, P. Lemanceau, L. Ranjard, and C. Mougel, 2005: Assessing genetic structure and diversity of airborne bacterial communities by DNA fingerprinting and 16S rDNA clone library. Atmos. Environ., 39, 3687-3695, doi:10.1016/j.atmosenv.2005.03.002.

Merrill, L., J. Dunbar, J. Richardson, and C. R. Kuske, 2006: Composition of Bacillus species in aerosols from 11 U.S. cities. J. Forensic Sci., 51, 559-565, doi:10.1111/ j.1556-4029.2006.00132.x.

Morris, C., D. Sands, M. Bardin, R. Jaenicke, B. Vogel, C. Leyronas, P. Ariya, and R. Psenner, 2011: Microbiology and atmospheric processes: Research challenges concerning the impact of airborne micro-organisms on the atmosphere and climate. Biogeosciences, 8, 17-25, doi:10.5194/ bg-8-17-2011.

O'Dowd, C. D., and Coauthors, 2004: Biogenically driven organic contribution to marine aerosol. Nature, 431, 676-680, doi:10.1038/nature02959.

Peter, H., P. Hörtnagl, I. Reche, and R. Sommaruga, 2014: Bacterial diversity and composition during rain events with and without Saharan dust influence reaching a high mountain lake in the Alps. Environ. Microbiol. Rep., 6, 618-624, doi:10.1111/ 1758-2229.12175.

Polymenakou, P. N., M. Mandalakis, E. G. Stephanou, and A. Tselepides, 2008: Particle size distribution of airborne microorganisms and pathogens during an intense African dust event in the eastern Mediterranean. Environ. Health Perspect., 116, 292-296, doi:10.1289/ehp.10684.

Pósfai, M., J. Li, J. R. Anderson, and P. R. Buseck, 2003: Aerosol bacteria over the Southern Ocean during ACE-1. Atmos. Res., 66, 231-240, doi:10.1016/S0169-8095(03)00039-5.

Sayers, E. W., and Coauthors, 2011: Database resources of the National Center for Biotechnology Information. Nucleic Acids Res., 39, D38-D51, doi:10.1093/nar/gkq1172.

Schloss, P. D., and Coauthors, 2009: Introducing mothur: Opensource, platform-independent, community-supported software for describing and comparing microbial communities. Appl. Environ. Microbiol., 75, 7537-7541, doi:10.1128/ AEM.01541-09.

, D. Gevers, and S. L. Westcott, 2011: Reducing the effects of PCR amplification and sequencing artifacts on 16S rRNA-based studies. PLoS One, 6, e27310, doi:10.1371/ journal.pone.0027310.

Smith, D. J., D. A. Jaffe, M. N. Birmele, D. W. Griffin, A. C. Schuerger, J. Hee, and M. S. Roberts, 2012: Free tropospheric transport of microorganisms from Asia to North America. Microb. Ecol., 64, 973-985, doi:10.1007/s00248-012-0088-9.

—, H. J. Timonen, D. A. Jaffe, D. W. Griffin, M. N. Birmele, K. D. Perry, P. D. Ward, and M. S. Roberts, 2013: Intercontinental dispersal of bacteria and archaea by transpacific winds. Appl. Environ. Microbiol., 79, 1134-1139, doi:10.1128/ AEM.03029-12.

Sogin, M. L., H. G. Morrison, J. A. Huber, D. M. Welch, S. M. Huse, P. R. Neal, J. M. Arrieta, and G. J. Herndl, 2006: Microbial diversity in the deep sea and the underexplored "rare 
biosphere." Proc. Natl. Acad. Sci. USA, 103, 12 115-12 120, doi:10.1073/pnas.0605127103.

Sun, J., and P. A. Ariya, 2006: Atmospheric organic and bio-aerosols as cloud condensation nuclei (CCN): A review. Atmos. Environ., 40, 795-820, doi:10.1016/j.atmosenv.2005.05.052.

Tamura, K., J. Dudley, M. Nei, and S. Kumar, 2007: MEGA4: Molecular evolutionary genetics analysis (MEGA) software version 4.0. Mol. Biol. Evol., 24, 1569-1599, doi:10.1093/ molbev/msm092.

Tan, S.-C., X. Yao, H.-W. Gao, G.-Y. Shi, and X. Yue, 2013: Variability in the correlation between Asian dust storms and chlorophyll $a$ concentration from the north to equatorial Pacific. PLoS One, 8, e57656, doi:10.1371/journal.pone.0057656.

Thompson, J. R., L. A. Marcelino, and M. F. Polz, 2005: Diversity, sources, and detection of human bacterial pathogens in the marine environment. Oceans and Health: Pathogens in the Marine Environment, S. Belkin and R. Colwell, Eds., 29-68, doi:10.1007/0-387-23709-7_2.
Tsai, Y.-L., and B. H. Olson, 1991: Rapid method for direct extraction of DNA from soil and sediments. Appl. Environ. Microbiol., 57, 1070-1074.

Uno, I., and Coauthors, 2009: Asian dust transported one full circuit around the globe. Nat. Geosci., 2, 557-560, doi:10.1038/ngeo583.

Williamson, A., and H. Gotaas, 1942: Aerosol sterilization of airborne bacteria. Amer. Ind. Hyg. Assoc. Quart., 3, 40-45, doi:10.1080/00968204209343817.

Yu, Y., C. Lee, J. Kim, and S. Hwang, 2005: Group-specific primer and probe sets to detect methanogenic communities using quantitative real-time polymerase chain reaction. Biotechnol. Bioeng., 89, 670-679, doi:10.1002/ bit.20347.

Yukimura, K., R. Nakai, S. Kohshima, J. Uetake, H. Kanda, and T. Naganuma, 2009: Spore-forming halophilic bacteria isolated from Arctic terrains: Implications for long-range transportation of microorganisms. Polar Sci., 3, 163-169, doi:10.1016/j.polar.2009.07.002. 